\title{
平成 29 年度一般社団法人日本風工学会年次研究発表会・社員総会報告 Report on the 2017 Annual Meeting of JAWE
}

長谷部 寛*

Hiroshi HASEBE

平成 29 年度一般社団法人日本風工学会年次研究発表 会および社員総会が, 平成 29 年 5 月 24 日 (水), 25 日 (木) の両日, 新潟工科大学南棟 S1 大講義室 (写真 1 参照) を 会場として開催された。2 日間合計で 10 セッション 53 編の研究発表が行われ, 活発な議論がなされた。参加者 は名誉会員 2 名, 正会員 74 名, 賛助会員 1 名, 学生会員 13 名，非会員 2 名の合計 92 名であつた。

第 1 日目は午前 9 時 30 分から開始された。研究発表に 先立ち, 富永禎秀実行委員長 (新潟工科大学) 加挨拶 があり (写真 2 参照), 新潟工科大学に風洞が設置された 経緯と，柏崎と風の間に密接な関係があることなどの話 があった。その後, 5 セッション, 26 編の研究発表が行 われた (写真 3 参照)。

午後 3 時 30 分からは, 国立研究開発法人防災科学技術 研究所 雪水防災研究センター センター長の上石勲氏に

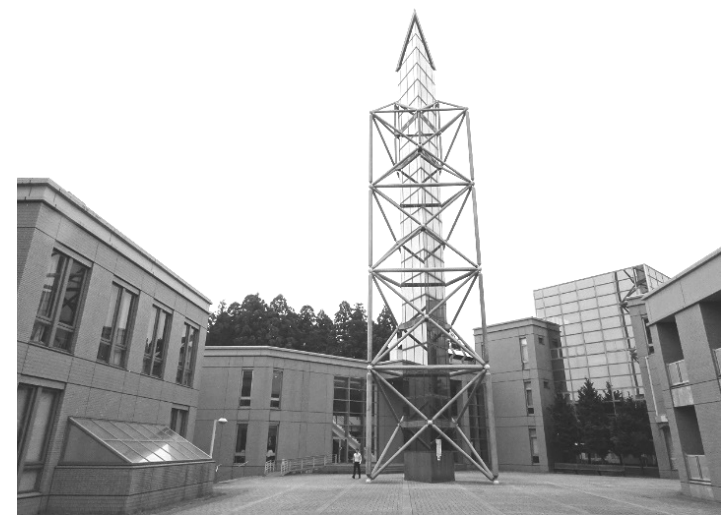

写真 1 新潟工科大学キャンパス
による「雪水災害予測システムと気象災害軽減イノベー ションハブ」と題した特別講演が行われた(写真4参照)。 防災科学技術研究所雪水防災研究センターの取り組み

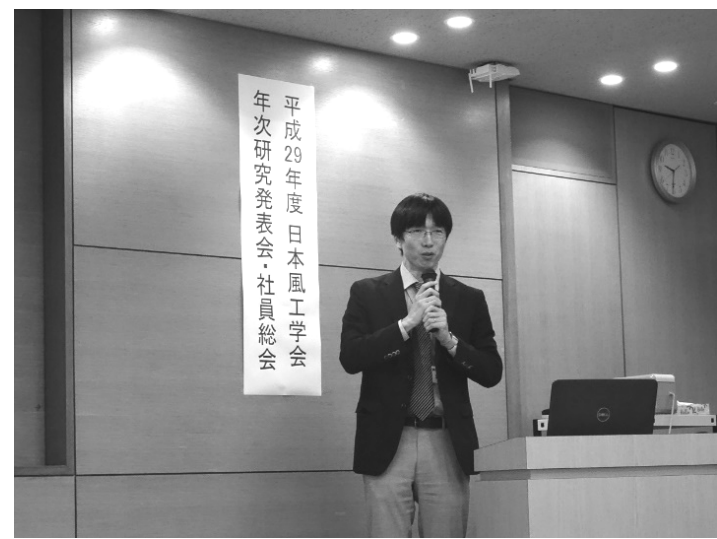

写真 2 富永禎秀実行委員長による開会挨拶

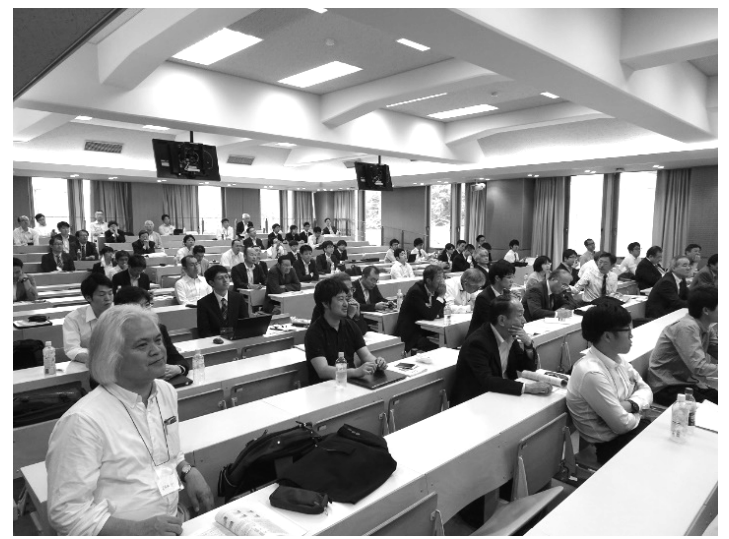

写真 3 会場内の様子

* 日本大学理工学部土木工学科 准教授 (運営・学術委員会 幹事) Associate Professor, Department of Civil Engineering, College of Science and Technology, Nihon University 
を中心として，雪崩災害とその調査の実態，雪の性質， 吹雪や着雪などによる事故とその対策, 今後の計画など 多岐に渡る講演内容であった。雪崩災害の調査に関わる 話題の中で, 雪を掘ってその断面にインクをかけると, 通常の雪は層状の筋が見えるのに対して, 雪崩はいっさ い筋が見られない。このような方法で雪崩の範囲を把握 しているという説明があり, 雪崩の雪の性質を知ること ができた。今回の年次研究発表会の中にも，風と雪に関 する発表もあり，風と雪の密接さを再認識する有意義な 特別講演となった。

午後 4 時 30 分からは同会場において, 一般社団法人日 本風工学会平成 29 年度社員総会が開催された。その後, 会場を福利厚生棟 1 階食堂 granF に移して㭛親会が開か れた。懇親会には，(おそらく本会にとって初めての出来 事と思われるが）櫻井雅浩柏崎市長, 大川秀雄新潟工科 大学学長が参加され, 祝辞をいただいた。参加者は 80 名 にものぼり, 年齢や職域の枠を超えて交流した。野村卓 史会長 (日本大学) の開会挨拶, 櫻井市長の祝辞, 大川 学長の祝辞・乾杯で始まった会には, 柏崎名物の鯛の料 理や, 新潟工科大学から提供された地酒などが用意され ており, 新潟・柏崎の味を存分に堪能することができた。 また, 昨年の本会 40 周年を記念して立川俱子様より提供 されたワインも振舞われた。恒例の風工学会賞等受賞者 によるスピーチでは, 受賞者の受賞に対する思いや本会 の思い出など，様々なエピソードを知ることができた。

第 2 日目は午前 9 時 30 分からセッションが開始され, 午後 3 時 30 分まで 5 セッション 27 編の研究発表が行わ れ，1 日目に引き続き活発な討議が行われた。閉会にあた っては, 白土博通運営・学術委員会委員長 (京都大学) より閉会の挨拶があった。その中で，来年の年次大会は 東京地区にてオーガナイズドセッション形式の開催とな ることが発表され，2 日間の予定を無事終了した。

今回の年次大会では，メロンテクノス株式会社の技術 展示ブース（風圧センサー等の展示）が設けられた。休 㲘時間に多くの参加者が展示ブースを訪れ，説明を熱心 に聴く様子が見受けられた。さらに, 両日に渡り新潟工 科大学の風洞見学会が企画された。

最後に, 今回の年次大会の開催にあたり多大なるご尽 力をいただいた開催校の富永禎秀教授, 会場設営から当 日の運営補助, 実験室見学にご協力くださった富永研究 室の学生の皆様に厚く御礼申し上げます。

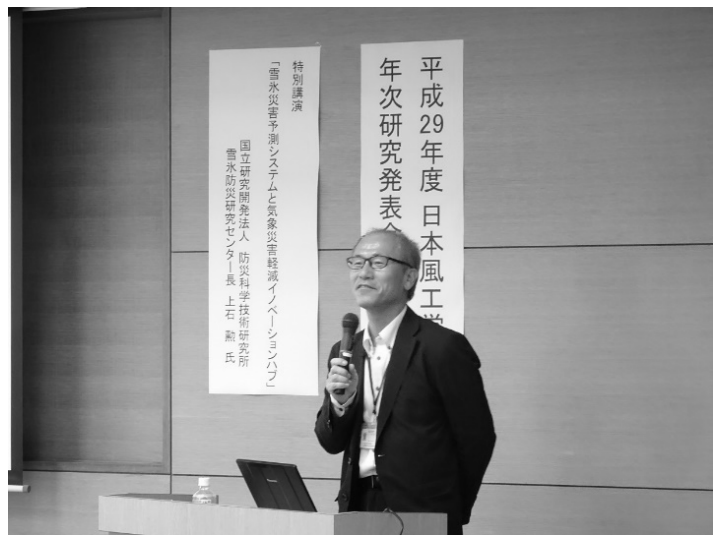

写真 4 上石勲氏による特別講演

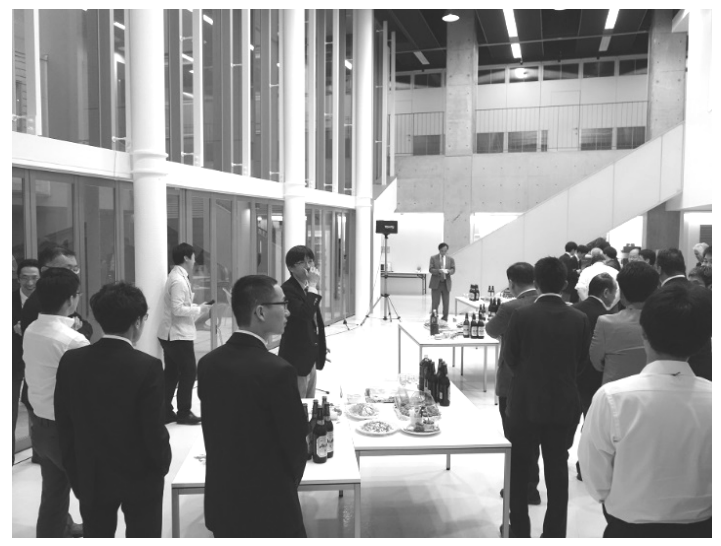

写真 5 懇親会の様子

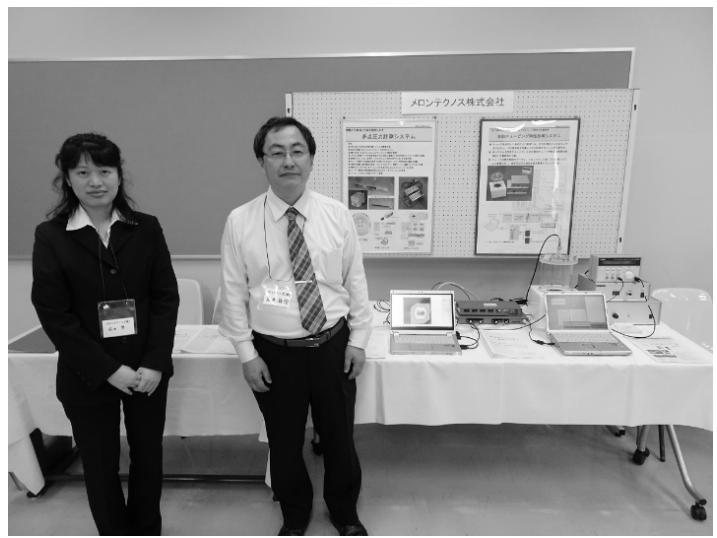

写真 6 メロンテクノス株式会社による技術展示 